\title{
EVALUASI STANDAR AKUNTANSI KEUANGAN \\ ENTITAS MIKRO KECIL DAN MENENGAH (SAK EMKM) \\ TAHUN 2018 PADA USAHA SINAR TERANG DI SAMARINDA
}

\author{
Pandu Prahadi Pangestu \\ Elfreda Aplonia Lau \\ Sunarto
}

\author{
University of 17 Agustus 1945 Samarinda \\ Jl. Ir. H. Juanda No. 80, 75124, Indonesia \\ elfredalau9@gmail.com
}

\begin{abstract}
This study aims to evaluate whether the recognition of items in financial statements, measurement of financial statement elements, presentation of items in financial statements and disclosure of financial statements in Sinar Terang Business are in accordance with the provisions in Micro, Small and Medium Entity Financial Accounting Standards (SAK EMKM) 2018.

The theory used in this study is financial accounting. The hypothesis stated is the recognition of accounts in financial statements, measurement of financial statements, presentation of items in financial statements, and disclosure of financial statements not in accordance with the 2018 Micro, Small and Medium Entity Accounting Standards (SAK EMKM).

The analysis technique used in this study is a comparative descriptive method, which is a method that compares accounting treatment that includes recognition, measurement, presentation and disclosure based on SAK EMKM 2018 with recognition, measurement, presentation and disclosure in Sinar Business and Champion methods for calculating checklist value in determining conformity criteria.

The results of the study indicate that the recognition and measurement of the items in the financial statements of Sinar Terang Business are not in accordance with SAK EMKM. Whereas the presentation and disclosure of financial statements for Sinar Terang Business do not match the SAK EMKM
\end{abstract}

Keywords: Recognition, Measurement, Presentation, Disclosure, SAK EMKM

PENDAHULUAN

Usaha Mikro, Kecil dan Menengah (UMKM) sebagian besar dilakukan oleh kaum menengah kebawah karena dalam mendirikan usaha ini sangat mudah dan tidak memerlukan modal yang besar.
Kehadiran UMKM membantu pemerintah dalam hal menciptakan lapangan kerja sekaligus dapat mengurangi angka pengangguran yang ada serta berkontribusi terhadap pertumbuhan ekonomi di Indonesia. 
UMKM berkontribusi terhadap pembangunan fisik maupun pembangunan manusia bangsa Indonesia, tentu saja mengundang perhatian dari Ikatan Akuntan Indonesia(IAI) untuk mengeluarkan standar akuntansi keuangan khusus untuk pelaku UMKM. UMKM sedikit dipermudah dengan adanya Standar Akuntansi Keuangan Entitas Mikro, Kecil, dan Menengah (SAK EMKM) yang diterbitkan oleh IAI yang dimana Exposure Draft Standar Akuntansi Keuangan Entitas Mikro, Kecil, dan Menengah (ED SAK EMKM) telah disetujui Dewan Standar Akuntansi Keuangan dan diresmikan mulai tanggal 1 Januari 2018. Dengan adanya SAK EMKM dapat membantu memudahkan pelaku UMKM dalam mengaplikasikan akuntansi pada usahanya sehingga dapat dengan mudah menyusun laporan keuangan sesuai dengan standar.

Penyusunan laporan keuangan berdasarkan pada standar akuntansi keuangan merupakan suatu bentuk peningkatan kualitas laporan keuangan, yang akan memberikan dampak dalam peningkatkan kredibilitas laporan keuangan yang dimaksud.

Pada umumnya UMKM mengalami kendala pada kurangnya keterampilan yang dimiliki dalam bidang akuntansi sehingga kegiatan operasional perusahaannya dicatat dengan hanya melakukan pembukuan sederhana yakni mencatat jumlah barang diterima dan dikeluarkan, jumlah barang dibeli dan dijual, dan jumlah piutang dan hutang serta dalam menghitung laba rugi usaha dilakukan dengan cara menghitung seluruh jumlah pemasukan lalu dikurangi dengan jumlah pengeluaran atas transaksi yang terjadi pada setiap bulannya. Hal ini terjadi pula pada Usaha Sinar Terang. Sepatutnyalah, Usaha Sinar Terang dapat mematuhi dan menerapkan SAK EMKM sebagai standar pelaporan keuangan agar memberikan informasi keuangan yang berguna bagi banyak pihak.

Perlakuan akuntansi seperti pengakuan, pengukuran, penyajian, dan pengungkapan dalam laporan keuangan Usaha Sinar Terang atas transaksi usahanya sangat perlu diperhatikan dan dievaluasi berdasarkan SAK EMKM, sehingga dapat diketahui tingkat kesesuaian yang telah dicapai Usaha Sinar Terang serta menunjukkan cara pemberlakuan yang sebenarnya. 
Berdasarkan paparan tersebut dipandang perlu dilakukan telaah terhadap research question berikut :

1. Apakah pengakuan pos-pos dalam laporan keuangan pada Usaha Sinar Terang sesuai dengan ketentuan Standar Akuntansi Keuangan Entitas Mikro Kecil dan Menengah (SAK EMKM) Tahun 2018?

2. Apakah pengukuran unsur laporan keuangan pada Usaha Sinar Terang telah sesuai dengan Standar Akuntansi Keuangan Entitas Mikro Kecil dan Menengah (SAK EMKM) Tahun 2018?

3. Apakah penyajian pos-pos dalam laporan keuangan pada Usaha Sinar Terang sesuai ketentuan Standar Akuntansi Keuangan Entitas Mikro Kecil dan Menengah (SAK EMKM) Tahun 2018?

4. Apakah pengungkapan laporan keuangan yang disusun oleh Usaha Sinar Terang sesuai ketentuan dalam Standar Akuntansi Keuangan Entitas Mikro Kecil dan Menengah (SAK EMKM) Tahun 2018?

\section{KERANGKA TEORITIS}

Teori yang mendasari penelitian ini adalah teori akuntansi keuangan yang berfokus pada pengakuan, pengukuran, penyajian dan pengungkapan laporan keuangan. Beberapa pengertian akuntansi keuangan diketengahkan oleh para pakar berikut ini.

Menurut Kieso et al (2016:4): "Financial accounting is the process that culminate in the preparation of financial reports on the enterprise for use by both internal and external parties". Akuntansi keuangan adalah proses yang berujung pada penyusunan laporan keuangan perusahaan untuk digunakan oleh pihak internal maupun eksternal.

Laporan keuangan oleh Munawir (2018:2) didefinisikan sebagai "hasil dari proses akuntansi yang dapat digunakan sebagai alat untuk berkomunikasi antara data keuangan atau aktivitas sesuatu perusahaan dengan pihak-pihak yang berkepentingan dengan data atau aktivitas perusahaan tersebut".

Berdasarkan definisi laporan keuangan tersebut, disimpulkan bahwa laporan keuangan adalah hasil dari serangkaian proses akuntansi dimulai dari proses pencatatan, penggabungan, dan pengikhtisaran semua transaksi yang dilakukan perusahaan dalam satu periode akuntansi yang dilakukan oleh perusahaan dalam satu periode 
akuntansi sebagai alat komunikasi yang digunakan oleh pihak-pihak berkepentingan.

Laporan keuangan menurut Ikatan Akuntansi Indonesia (IAI) dalam Standar Akuntansi Keuangan untuk Entitas Mikro, Kecil, dan Menengah (SAK EMKM) (2018: 2.1) bertujuan menyediakan informasi posisi keuangan dan kinerja keuangan suatu entitas yang bermanfaat bagi sejumlah besar pengguna dalam pengambilan keputusan ekonomi oleh siapapun yang tidak dalam posisi dapat meminta laporan keuangan khusus untuk memenuhi kebutuhan informasi tersebut.

Mengacu pada pendapat tersebut, disimpulkan bahwa laporan keuangan bertujuan menyediakan informasi mengenai posisi keuangan, kinerja keuangan dan laporan arus kas pada suatu entitas atau organisasi yang akan bermanfaat bagi pengguna laporan keuangan dalam proses pengambilan keputusan bisnis atau ekonomi.

Laporan keuangan minimum menurut Standar Akuntansi Keuangan Entitas Mikro, Kecil dan Menengah (2018:3.19) terdiri dari: Laporan posisi keuangan pada akhir periode; Laporan laba rugi selama periode; dan Catatan atas laporan keuangan, yang berisi tambahan dan rincian pos-pos tertentu yang relevan.

\section{Pengakuan Unsur Laporan} Keuangan Berdasarkan SAK EMKM

Pengertian pengakuan menurut SAK EMKM (2018:2.12) yaitu : Proses pembentukan suatu pos dalam laporan posisi keuangan atau laporan laba rugi yang memenuhi definisi suatu unsur dan memenuhi kriteria sebagai berikut :

a. Manfaat ekonomik yang terkait dengan pos tersebut dapat dipastikan akan mengalir ke dalam atau keluar dari entitas; dan

b. Pos tersebut memiliki biaya yang dapat diukur dengan andal.

Termaktup dalam SAK EMKM (2018:2.22-2.25) bahwa unsur laporan keuangan meliputi:

1. Aset diakui dalam laporan posisi keuangan ketika manfaat ekonomiknya di masa depan dapat dipastikan akan mengalir ke dalam entitas dan aset tersebut memiliki biaya yang dapat diukur dengan andal. Aset tidak diakui dalam laporan posisi keuangan jika manfaat ekonimiknya dipandang tidak mungkin mengalir ke dalam entitas walaupun pengeluaran telah terjadi. Sebagai alternative, transaksi 
tersebut menimbulkan pengakuan beban dalam laporan laba rugi.

2. Liabilitasdiakui dalam laporan posisi keuangan jika pengeluaran sumber daya yang mengandung manfaat ekonomik dipastikan akan dilakukan untuk menyelesaikan kewajiban entitas dan jumlah yang harus diselesaikan dapat diukur secara andal.

3. Penghasilan

Penghasilan diakui dalam laporan laba rugi jika kenaikan manfaat ekonomik di masa depan yang berkaitan dengan kenaikan aset atau penurunan liabilitas telah terjadi dan dapat diukur secara andal.

4. Beban diakui dalam laporan laba rugi jika penurunan manfaat ekonomik dimasa depan yang berkaitan dengan penurunan aset atau kenaikan liabilitas telah terjadi dan dapat diukur secara andal.

\section{Pengukuran Laporan Keuangan Berdasarkan SAK EMKM}

SAK EMKM $\quad(2018: 2.15)$ menjelaskan bahwa pengukuran adalah "proses penetapan jumlah uang untuk mengakui aset, liabilitas, penghasilan dan beban di dalam laporan keuangan".

SAK EMKM $\quad(2018: 2.16)$ menambahkan mengenai dasar pengukuran unsur laporan keuangan dalam SAK EMKM adalah biaya historis yang dapat dijelaskan sebagai berikut :

1. Biaya historis suatu aset adalah sebesar jumlah kas atau setara kas yang dibayarkan untuk memperoleh aset tersebut pada saat perolehan.

2. Biaya historis suatu libilitas adalah sebesar jumlah kas atau setara kas yang diterima atau jumlah kas yang diperkirakan akan dibayarkan untuk memenuhi liabilitas dalam pelaksanaan usaha normal.

\section{Penyajian Laporan Keuangan} Berdasarkan SAK EMKM

Penyajian yang wajar dari laporan keuangan SAK EMKM antara lain dijelaskan dalam SAK EMKM (2018: 3.1-3.11) sebagai berikut:

1. Penyajian Wajar

Penyajian wajar mensyaratkan penyajian jujur atas pengaruh transaksi, peristiwa, dan kondisi lain yang sesuai dengan definisi dan kriteria pengakuan aset, liabilitas, penghasilan, dan beban. Pengungkapan diperlukan ketika kepatuhan atas persyaratan tertentu dalam SAK EMKM tidak memadai bagi pemakai untuk memahami pengaruh dari transaksi, peristiwa, 
dan kondisi lain atas posisi dan kinerja keuangan entitas. SAK EMKM paragraf 3.3 juga menjelaskan bahwa penyajian wajar laporan keuangan mensyaratkan entitas untuk menyajikan informasi untuk mencapai tujuan sebagai berikut:

a. Relevan: informasi dapat digunakan oleh pengguna untuk proses pengambilan keputusan.

b. Representasi tepat: informasi disajikan secara tepat atau secara apa yang seharusnya disajikan dan bebas dari kesalahan material dan bias.

c. Keterbandingan: informasi dalam laporan keuangan entitas dapat dibandingkan antar periode untuk mengidentifikasi kecenderungan posisi dan kinerja keuangan. Informasi dalam laporan keuangan entitas juga dapat dibandingkan antar entitas untuk mengevaluasi posisi dan kinerja keuangan.

d. Keterpahaman: informasi yang disajikan dapat dengan mudah dipahami oleh pengguna.

2. Kepatuhan Terhadap SAK EMKM Entitas yang laporan keuangannya telah patuh terhadap SAK EMKM membuat pernyataan secara eksplisit dan tanpa kecuali tentang kepatuhan terhadap SAK EMKM dalam catatan atas laporan keuangan. Entitas tidak dapat mendeskripsikan bahwa laporan keuangan telah patuh terhadap SAK EMKM, kecuali laporan keuangan tersebut telah patuh terhadap seluruh persyaratan dalam SAK EMKM.

3. Frekuensi Pelaporan

Entitas menyajikan secara lengkap laporan keuangan pada akhir setiap periode pelaporan, termasuk informasi komparatifnya.

4. Penyajian yang Konsisten

Penyajian dan klasifikasi akun-akun dalam laporan keuangan antar periode entitas disusun secara konsisten, kecuali:

a. Telah terjadi perubahan yang signifikan atas sifat operasi entitas atau jika perubahan penyajian atau klasifikasi akunakun dalam laporan keuangan menghasilkan penyajian yang lebih sesuai dengan mempertimbangkan kriteria pemilihan dan penerapan kebijakan akuntansi; atau

b. SAK EMKM mensyaratkan perubahan penyajian. 
5. Informasi Komparatif

Kecuali dinyatakan lain oleh SAK EMKM, entitas menyajikan informasi komparatif yaitu informasi satu periode sebelumnya untuk seluruh jumlah yang disajikan dalam laporan keuangan periode berjalan.

6. Laporan Keuangan Lengkap

Dalam SAK EMKM paragraf 3.9, Laporan keuangan minimum terdiri dari:

a. Laporan posisi keuangan pada akhir periode;

b. Laporan laba rugi selama periode;

c. Catatan atas laporan keuangan, yang berisi tambahan dan rincian akun akun tertentu yang relevan. Karena dalam SAK EMKM tahun 2018 paragraf 3.8 mensyaratkan jumlah komparatif, maka laporan keuangan lengkap berarti bahwa entitas menyajikan minimum dua periode untuk setiap laporan keuangan yang disyaratkan dan catatan atas laporan keuangan yang terkait.

7. Identifikasi Laporan Keuangan

Entitas mengidentifikasi secara jelas setiap laporan keuangan dan catatan atas laporan keuangan. Selain itu, entitas menunjukkan informasi berikut dengan jelas dan diulangi bilamana perlu untuk pemahaman informasi yang disajikan :

a. Nama entitas yang menyusun dan menyajikan laporan keuangan;

b. Tanggal akhir periode pelaporan dan periode laporan keuangan;

c. Rupiah sebagai mata uang penyajian; dan

d. Pembulatan angka yang digunakan dalam penyajian laporan keuangan.

\section{Pengungkapan Laporan Keuangan SAK EMKM}

Berdasarkan SAK EMKM (2018:3.9) disebutkan bahwa komponen laporan keuangan entitas meliputi:

a. Laporan Posisi Keuangan

SAK EMKM

$(2018: 4.1)$

menyatakan laporan posisi keuangan menyajikan informasi tentang aset, liabilitas, dan ekuitas entitas pada akhir periode pelaporan. Menurut SAK EMKM (2018:4.2) laporan keuangan entitas dapat mencakup akun-akun berikut: kas dan setara kas; piutang; persediaan; aset tetap; utang usaha; utang bank; ekuitas.

b. Laporan Laba Rugi

Pada SAK EMKM (2018:5.1) mensyaratkan entitas untuk 
menyajikan laporan laba rugi yang merupakan kinerja keuangan entitas untuk suatu periode. Berdasarkan SAK EMKM (2018:5.2) menyebutkan bahwa laporan laba rugi mencakup pos-pos sebagai berikut: Pendapatan; Beban keuangan; Beban pajak

c. Catatan atas Laporan Keuangan

Catatan atas laporan keuangan berisi informasi sebagai tambahan informasi yang disajikan dalam laporan keuangan. Menurut SAK EMKM (2018:6.2) catatan atas laporan keuangan memuat :

a. suatu pernyataan bahwa laporan keuangan telah disusun sesuai dengan SAK EMKM; b. ikhtisar kebijakan akuntansi;

c. informasi tambahan dan rincian akun tertentu yang menjelaskan transaksi penting dan material sehingga bermanfaat bagi pengguna untuk memahami laporan keuangan. Jenis informasi tambahan dan rincian yang disajikan bergantung pada jenis kegiatan usaha yang dilakukan oleh entitas. Setiap akun dalam laporan keuangan merujuk-silang ke informasi terkait dalam catatan atas laporan keuangan.

\section{Kerangka Pikir}

Kerangka pikir penelitian ini dapat digambarkan sebagai berikut :

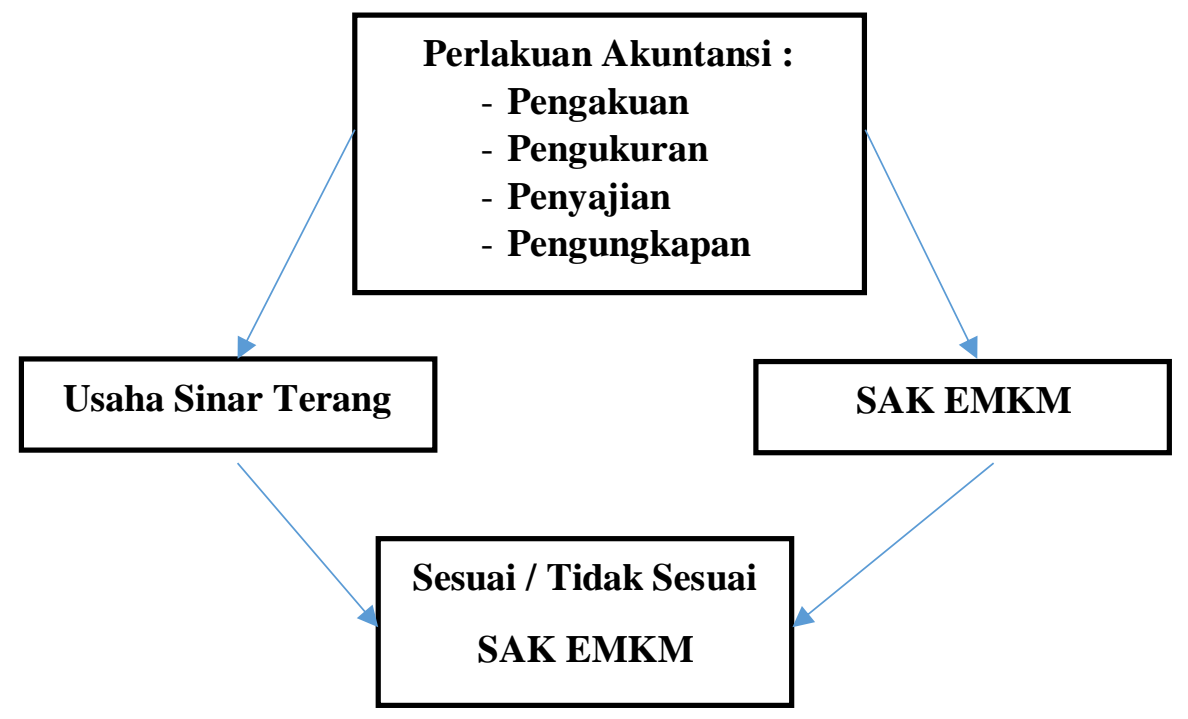

Gambar 1. Kerangka Pikir 


\section{Hipotesis}

Berdasarkan permasalahan dan dasar teori, maka hipotesis penelitian ini sebagai berikut :

1. Pengakuan pos-pos dalam laporan keuangan pada Usaha Sinar Terang tidak sesuai Standar Akuntansi Keuangan Entitas Mikro Kecil dan Menengah (SAK EMKM) Tahun 2018.

2. Pengukuran laporan keuangan pada Usaha Sinar Terang tidak sesuai Standar Akuntansi Keuangan Entitas Mikro Kecil dan Menengah (SAK EMKM) Tahun 2018.

3. Penyajian pos-pos dalam laporan keuangan pada Usaha Sinar Terang tidak sesuai Standar Akuntansi Keuangan Entitas Mikro Kecil dan Menengah (SAK EMKM) Tahun 2018.

4. Pengungkapan laporan keuangan yang disusun oleh Usaha Sinar Terang tidak sesuai Standar Akuntansi Keuangan Entitas Mikro Kecil dan Menengah (SAK EMKM) Tahun 2018.

\section{METODE PENELITIAN}

\section{Definisi}

1. Pengakuan merupakan proses pembentukan pos-pos dalam laporan posisi keuangan atau laporan laba rugi pada Usaha Sinar Terang yang memenuhi definisi suatu unsur dan memenuhi kriteria dalam SAK EMKM Tahun 2018.

2. Pengukuran merupakan proses penetapan jumlah uang untuk mengakui aset, liabilitas, penghasilan dan beban dalam laporan keuangan Usaha Sinar Terang.

3. Penyajian merupakan sebuah proses penempatan suatu akun secara terstruktur pada laporan keuangan Usaha Sinar Terang.

4. Pengungkapan merupakan sebuah proses penjelasan secara naratif atau rincian angka-angka yang tertera dalam laporan neraca, laporan laba rugi Usaha Sinar Terang. Penjelasan secara naratif terhadap pos-pos laporan keuangan diungkapakan dalam Catatan atas Laporan Keuangan (CaLK).

5. Laporan posisi keuangan merupakan sebuah laporan yang sistematis tentang posisi aktiva, kewajiban dan ekuitas Usaha Sinar Terang per tanggal tertentu.

6. Laporan laba rugi merupakan laporan sitematis tentang pendapatan dan beban Usaha Sinar Terang untuk satu periode tertentu 
7. Catatan atas laporan keuangan memberikan penjelasan yang lebih lengkap mengenai informasi yang disajikan dalam laporan keuangan Usaha Sinar Terang.

\section{Teknik Pengumpulan Data}

Teknik pengumpulan data yang digunakan untuk memperoleh data penelitian ini adalah pengumpulan data melalui wawancara yang dilakukan secara terstruktur kepada narasumber yang merupakan pemilik sekaligus bagian yang mengurusi keuangan Usaha Sinar Terang untuk mendapatkan data primer. Selain itu pengumpulan data dari dokumentasi pada Usaha Sinar Terang berupa profil perusahaan, data keuangan dan sebagainya.

\section{Metode Analisis}

Alat analisis yang digunakan dalam penelitian ini adalah sebagai berikut:

1. Analisis deskriptif komparatif, yaitu:

a. Membandingkan pengakuan pospos dalam laporan posisi keuangan atau laporan laba rugi berdasarkan SAK EMKM dengan menurut Usaha Sinar Terang.

b. Membandingkan pengukuran penetapan jumlah uang untuk mengakui aset, liabilitas, penghasilan dan beban di dalam laporan keuangan berdasarkan SAK EMKM dengan menurut Usaha Sinar Terang.

c. Membandingkan penyajian penempatan suatu akun secara terstruktur pada laporan keuangan berdasarkan SAK EMKM dengan menurut Usaha Sinar Terang.

d. Membandingkan pengungkapan penjelasan secara naratif atau rincian angka-angka yang tertera dalam laporan neraca dan laporan laba rugi berdasarkan SAK EMKM dengan menurut Usaha Sinar Terang.

2. Nilai persentase (Rumus Champions) yaitu:

Teknik menghitung kesesuaian dalam penelitian ini menggunakan rumus Champion yang oleh Dean J. Champion sebagai berikut: Persentase $=\frac{\sum \text { Jumlah jawaban "sesuai" }}{\sum \text { Total Pembanding }} \times 100 \%$

Hasil jawaban yang diperoleh dengan cara perhitungan diatas berguna untuk pengambilan kesimpulan, dengan klasifikasi kriteria nilai persentase sebagai berikut: 
Tabel 1 Klasifikasi kriteria Nilai Persentase

\begin{tabular}{cl}
\hline Persentase & \multicolumn{1}{c}{ Kriteria } \\
\hline $0 \%-25 \%$ & Dikategorikan tidak sesuai \\
\hline $26 \%-50 \%$ & Dikategorikan kurang sesuai \\
\hline $51 \%-75 \%$ & Dikategorikan cukup sesuai \\
\hline $76 \%-100 \%$ & Dikategorikan sesuai \\
\hline
\end{tabular}

Sumber : Dean J. Champions, 1990

\section{HASIL PENELITIAN}

\section{Data Poduksi dan Penjualan Usaha Sinar Terang Pada Bulan Januari 2019}

Data produksi Usaha Sinar Terang merupakan data yang berisi jumlah produksi amplang yang dihasilkan pada bulan Januari 2019 yang terdiri data jumlah bahan dalam proses sebanyak $400 \mathrm{~kg}$, bahan rusak pada saat produksi sebanyak $5 \mathrm{~kg}$, dan produk jadi sebanyak $395 \mathrm{~kg}$.

Data penjualan Usaha Sinar Terang merupakan data yang berisi jumlah produk amplang yang telah terjual selama bulan Januari 2019:

\section{Tabel 2. Data Penjualan Usaha Sianar Terang Pada Bulan Januari 2019}

\begin{tabular}{clccc}
\hline No & Jenis Ukuran Produk & $\begin{array}{c}\text { Penjualan } \\
\text { (Bungkus })\end{array}$ & $\begin{array}{c}\text { Retur } \\
\text { (Bungkus })\end{array}$ & $\begin{array}{c}\text { Penjualan Bersih } \\
\text { (Bungkus) }\end{array}$ \\
\hline 1 & Amplang 50g & 1010 & 13 & 997 \\
\hline 2 & Amplang 100g & 1430 & 27 & 1403 \\
\hline 3 & Amplang 180g & 970 & 10 & 960 \\
\hline 4 & Amplang 220g & 65 & 0 & 65 \\
\hline 5 & Amplang 350g & 36 & 0 & 36 \\
\hline
\end{tabular}

Sumber : Usaha Sinar Terang, 2019

Produk amplang dikemas dalam beberapa ukuran dengan harga yang berbeda-beda. Secara lengkap disajikan pada tabel sebagai berikut:

Tabel 3. Daftar Harga Produk Amplang Usaha Sinar Terang

\begin{tabular}{cllr}
\hline No. & \multicolumn{1}{c}{ Jenis Ukuran Produk } & \multicolumn{2}{c}{ Harga } \\
\hline 1 & Amplang 50g & $\mathrm{Rp}$ & 7.500 \\
\hline 2 & Amplang 100g & $\mathrm{Rp}$ & 13.000 \\
\hline 3 & Amplang 180g & $\mathrm{Rp}$ & 18.000 \\
\hline 4 & Amplang 220g & $\mathrm{Rp}$ & 25.000 \\
\hline 5 & Amplang 350g & $\mathrm{Rp}$ & 40.000 \\
\hline
\end{tabular}

Sumber : Usaha Sinar Terang, 2019 


\section{Data Laporan Pembukuan Usaha Sinar Terang Pada Bulan Januari 2019}

Data laporan pembukuan Usaha

Sinar Terang merupakan data yang

berisi seluruh kegiatan transaksi pemasukan dan pengeluaran yang telah dilakukan oleh Usaha Sinar Terang dalam bulan Januari 2019.

\section{Tabel 4 Laporan Pembukuan Usaha Sinar Terang Pada Bulan Januari 2019}

\begin{tabular}{|c|c|c|c|}
\hline Tanggal & Keterangan & Pemasukan (Rp) & Pengeluaran (Rp) \\
\hline \multirow[t]{6}{*}{ 07-Jan-19 } & Membeli ikan Pipih 320kg & & 17.600 .000 \\
\hline & Membeli Telur 15 piring & & 735.000 \\
\hline & Membeli Tepung Kanji 250kg & & 2.550 .000 \\
\hline & Membeli Bumbu-bumbu & & 2.000 .000 \\
\hline & Membeli Minyak Goreng 15 Jerigen & & 3.825 .000 \\
\hline & Membeli Gas LPG 2 tabung & & 340.000 \\
\hline 08-Jan-19 & Beli makan karyawan & & 150.000 \\
\hline 09-Jan-19 & Beli makan karyawan & & 150.000 \\
\hline 10-Jan-19 & Beli makan karyawan & & 150.000 \\
\hline \multirow[t]{2}{*}{ 11-Jan-19 } & Beli makan karyawan & & 150.000 \\
\hline & Bayar Upah karyawan pengolahan & & 4.500 .000 \\
\hline 12-Jan-19 & Beli makan karyawan & & 150.000 \\
\hline \multirow[t]{3}{*}{ 13-Jan-19 } & Beli makan karyawan & & 150.000 \\
\hline & Bayar Upah Pengemasan & & 300.000 \\
\hline & Membeli Bensin & & 250.000 \\
\hline \multirow[t]{11}{*}{ 14-Jan-19 } & Pembelian Eramart (Kredit) : & & \\
\hline & $50 \mathrm{~g}: 250$ bungkus & 1.875 .000 & \\
\hline & $100 \mathrm{~g}: 750$ bungkus & 9.750 .000 & \\
\hline & $180 \mathrm{~g}: 300$ bungkus & 5.400 .000 & \\
\hline & $220 \mathrm{~g}: 25 \mathrm{mika}$ & 625.000 & \\
\hline & Pembelian Iwan Swalayan : & & \\
\hline & $50 \mathrm{~g}: 150$ bungkus & 1.125 .000 & \\
\hline & $100 \mathrm{~g}: 100$ bungkus & 1.300 .000 & \\
\hline & $180 \mathrm{~g}: 100$ bungkus & 1.800 .000 & \\
\hline & $220 \mathrm{~g}: 10 \mathrm{mika}$ & 250.000 & \\
\hline & $350 \mathrm{~g}: 5$ mika & 200.000 & \\
\hline \multirow[t]{10}{*}{ 15-Jan-19 } & Pembelian Eramart Tenggarong: & & \\
\hline & 50g: 100 bungkus & 750.000 & \\
\hline & $100 \mathrm{~g}: 100$ bungkus & 1.300 .000 & \\
\hline & $180 \mathrm{~g}: 100$ bungkus & 1.800 .000 & \\
\hline & $220 \mathrm{~g}: 10 \mathrm{mika}$ & 250.000 & \\
\hline & $350 \mathrm{~g}: 5 \mathrm{mika}$ & 200.000 & \\
\hline & Retur 50g 6 Bungkus & & 45.000 \\
\hline & Retur 100g 17 Bungkus & & 221.000 \\
\hline & Membeli Bensin & & 200.000 \\
\hline & Pembelian customer di rumah $220 \mathrm{~g} 5$ mika & 125.000 & \\
\hline \multirow[t]{8}{*}{ 16-Jan-19 } & Pembelian Loa Bakung raya : & & \\
\hline & $50 \mathrm{~g}: 25$ bungkus & 187.500 & \\
\hline & 100g: 50 bungkus & 650.000 & \\
\hline & $180 \mathrm{~g}: 25$ bungkus & 450.000 & \\
\hline & Pembelian Warna Mart : & & \\
\hline & 50g : 50 bungkus & 375.000 & \\
\hline & $100 \mathrm{~g}: 50$ bungkus & 650.000 & \\
\hline & $180 \mathrm{~g}: 25$ bungkus & 450.000 & \\
\hline
\end{tabular}




\begin{tabular}{|c|c|c|c|}
\hline & \multicolumn{3}{|l|}{ Pembelian Coconut Mart: } \\
\hline & $50 \mathrm{~g}: 50$ bungkus & 375.000 & \\
\hline & $100 \mathrm{~g}: 80$ bungkus & 1.040 .000 & \\
\hline & $180 \mathrm{~g}: 30$ bungkus & 540.000 & \\
\hline & $220 \mathrm{~g}: 5 \mathrm{mika}$ & 125.000 & \\
\hline & \multicolumn{3}{|l|}{ Pembelian Jakarta Raya : } \\
\hline & $50 \mathrm{~g}: 30$ bungkus & 225.000 & \\
\hline & $100 \mathrm{~g}: 50$ bungkus & 650.000 & \\
\hline & $180 \mathrm{~g}: 30$ bungkus & 540.000 & \\
\hline 17-Jan-19 & \multicolumn{3}{|l|}{ Pembelian Planet Swalayan : } \\
\hline & $50 \mathrm{~g}: 80$ bungkus & 600.000 & \\
\hline & $100 \mathrm{~g}: 50$ bungkus & 650.000 & \\
\hline & $180 \mathrm{~g}: 50$ bungkus & 900.000 & \\
\hline & $220 \mathrm{~g}: 5 \mathrm{mika}$ & 125.000 & \\
\hline & $350 \mathrm{~g}: 5 \mathrm{mika}$ & 200.000 & \\
\hline & \multicolumn{3}{|l|}{ Pembelian Mulawarman Mart : } \\
\hline & $50 \mathrm{~g}: 50$ bungkus & 375.000 & \\
\hline & $100 \mathrm{~g}: 50$ bungkus & 650.000 & \\
\hline & $180 \mathrm{~g}: 50$ bungkus & 900.000 & \\
\hline & \multicolumn{3}{|l|}{ Pembelian XS Mart : } \\
\hline & $50 \mathrm{~g}: 100$ bungkus & 750.000 & \\
\hline & $100 \mathrm{~g}: 23$ bungkus & 299.000 & \\
\hline & $180 \mathrm{~g}: 50$ bungkus & 900.000 & \\
\hline & $350 \mathrm{~g}: 5 \mathrm{mika}$ & 200.000 & \\
\hline \multirow[t]{10}{*}{ 19-Jan-19 } & Membeli Bensin & & 250.000 \\
\hline & \multicolumn{3}{|l|}{ Pembelian UKM Center Balikpapan : } \\
\hline & $50 \mathrm{~g}: 112$ bungkus & 840.000 & \\
\hline & $100 \mathrm{~g}: 100$ bungkus & 1.300 .000 & \\
\hline & $180 \mathrm{~g}: 200$ bungkus & 3.600 .000 & \\
\hline & $220 \mathrm{~g}: 5 \mathrm{mika}$ & 125.000 & \\
\hline & $350 \mathrm{~g}: 16$ mika & 640.000 & \\
\hline & Retur $50 \mathrm{~g} 7$ bungkus & & 52.500 \\
\hline & Retur $100 \mathrm{~g} 10$ bungkus & & 130.000 \\
\hline & Retur $180 \mathrm{~g} 10$ bungkus & & 180.000 \\
\hline 20-Jan-19 & Bayar service mobil & & 450.000 \\
\hline 25-Jan-19 & Bayar Gaji & & 4.000 .000 \\
\hline \multirow[t]{2}{*}{ 21-Jan-19 } & Membayar air & & 335.821 \\
\hline & Membayar Listrik & & 379.585 \\
\hline 30-Jan-19 & Bayar Utang Bank & & 2.422 .000 \\
\hline TOTAL & & 46.081 .500 & 41.665 .906 \\
\hline LABA & & 4.35 & \\
\hline
\end{tabular}

Sumber : Usaha Sinar Terang,2019

\section{ANALISIS DAN PEMBAHASAN}

\section{Analisis}

\begin{tabular}{lrrlrl} 
Analisis & Deskriptif & \multicolumn{1}{c}{ Komparatif } & EMKM & Dengan Yang Dilakukan \\
Pengakuan & Berdasarkan & SAK & Oleh Usaha Sinar Terang &
\end{tabular}

Nilai kesesuaian pengakuan pospos dalam laporan keuangan 
berdasarkan SAK EMKM dengan yang dilakukan pada Usaha Sinar Terang, dapat diikuti pada tabel 6

Hasil perhitungan checklist kesesuaian pengakuan pos-pos dalam laporan keuangan adalah:

Persentase

$\frac{\sum \text { Jumlah jawaban "sesuai" }}{\sum \text { Total Pembanding }} \times 100 \%$ $=$

$$
=\frac{4}{8} \times 100 \%=50 \%
$$

Berdasarkan kriteria kesesuaian menurut Champion, maka pengakuan pos-pos dalam laporan keuangan menurut Usaha Sinar Terang dikategorikan kurang sesuai dengan ketentuan dalam SAK EMKM Tahun 2018.

Tabel 5 Hasil Perhitungan Kesesuaian Pengakuan

\section{PENGAKUAN}

\begin{tabular}{|c|c|c|c|c|}
\hline \multirow[b]{2}{*}{ No. } & \multirow[b]{2}{*}{ Berdasarkan SAK EMKM } & \multirow{2}{*}{$\begin{array}{c}\text { Menurut Usaha Sinar } \\
\text { Terang }\end{array}$} & \multicolumn{2}{|c|}{ Kesesuaian } \\
\hline & & & Sesuai & $\begin{array}{l}\text { Tidak } \\
\text { Sesuai }\end{array}$ \\
\hline 1. & $\begin{array}{l}\text { Entitas mengakui aset dan } \\
\text { liabilitas keuangan hanya } \\
\text { ketika entitas menjadi salah } \\
\text { satu pihak dalam ketentuan } \\
\text { kontraktual aset dan liabilitas } \\
\text { keuangan tersebut. (Paragraf } \\
\text { 8.6) }\end{array}$ & $\begin{array}{l}\text { Usaha Sinar Terang } \\
\text { mengakui aset dan } \\
\text { liabilitas ketika menjadi } \\
\text { salah satu pihak dalam } \\
\text { ketentuan kontraktual } \\
\text { aset dan liabilitas }\end{array}$ & $\checkmark$ & \\
\hline 2. & $\begin{array}{l}\text { Entitas mengakui persediaan } \\
\text { ketika diperoleh, sebesar biaya } \\
\text { perolehannya. (Paragraf } 9.3 \text { ) }\end{array}$ & $\begin{array}{l}\text { Usaha Sinar Terang } \\
\text { mengakui persediaan } \\
\text { ketika diperoleh sebesar } \\
\text { biaya perolehannya }\end{array}$ & $\checkmark$ & \\
\hline 3. & $\begin{array}{l}\text { Aset tetap dicatat jika aset } \\
\text { tetap tersebut dimiliki secara } \\
\text { hukum oleh entitas sebesar } \\
\text { biaya perolehan. (Paragraf } \\
\text { 11.6) }\end{array}$ & $\begin{array}{l}\text { Usaha Sinar terang tidak } \\
\text { mencatat Aset tetap }\end{array}$ & & \\
\hline 4. & $\begin{array}{l}\text { Beban penyusutan diakui } \\
\text { dalam laporan laba rugi. } \\
\text { (Paragraf 11.13) }\end{array}$ & $\begin{array}{l}\text { Usaha Sinar Terang tidak } \\
\text { mengakui adanya beban } \\
\text { penyusutan }\end{array}$ & & $\checkmark$ \\
\hline 5. & $\begin{array}{l}\text { Entitas mengakui aset } \\
\text { takberwujud yang diperoleh } \\
\text { secara terpisah. (Paragraf } \\
12.3 \text { ) }\end{array}$ & $\begin{array}{l}\text { Usaha Sinar Terang tidak } \\
\text { memiliki aset } \\
\text { takberwujud }\end{array}$ & - & - \\
\hline
\end{tabular}




\section{PENGAKUAN}

\begin{tabular}{|c|c|c|c|c|}
\hline \multirow[b]{2}{*}{ No. } & \multirow[b]{2}{*}{ Berdasarkan SAK EMKM } & \multirow{2}{*}{$\begin{array}{l}\text { Menurut Usaha Sinar } \\
\text { Terang }\end{array}$} & \multicolumn{2}{|c|}{ Kesesuaian } \\
\hline & & & Sesuai & $\begin{array}{l}\text { Tidak } \\
\text { Sesuai }\end{array}$ \\
\hline 6. & $\begin{array}{l}\text { Ekuitas diakui sesuai dengan } \\
\text { peraturan perundangan yang } \\
\text { berlaku untuk badan usaha } \\
\text { tersebut (Paragraf 13.9) }\end{array}$ & $\begin{array}{l}\text { Usaha Sinar Terang tidak } \\
\text { mengakui ekuitas }\end{array}$ & & $\checkmark$ \\
\hline 7. & $\begin{array}{l}\text { Pendapatan diakui ketika } \\
\text { terdapat hak atas pembayaran } \\
\text { yang diterima atau yang masih } \\
\text { harus diterima baik pada masa } \\
\text { sekarang atau masa depan. } \\
\text { (Paragraf } 14.2 \text { ) }\end{array}$ & $\begin{array}{l}\text { Usaha Sinar Terang } \\
\text { mengakui pendapatan } \\
\text { atas pembayaran yang } \\
\text { diterima atau yang masih } \\
\text { harus diterima }\end{array}$ & $\checkmark$ & \\
\hline 8. & $\begin{array}{l}\text { Entitas mengakui penerimaan } \\
\text { hibah dalam laba rugi pada } \\
\text { saat hibah tersebut diterima } \\
\text { sebesar jumlah nominalnya. } \\
\text { (Paragraf 14.10) }\end{array}$ & $\begin{array}{l}\text { Usaha Sinar Terang tidak } \\
\text { menerima hibah }\end{array}$ & - & - \\
\hline 9. & $\begin{array}{l}\text { Beban diakui pada saat kas } \\
\text { dibayarkan. (Paragraf 14.15) }\end{array}$ & $\begin{array}{l}\text { Usaha Sinar terang } \\
\text { mengakui beban pada } \\
\text { saat kas dibayarkan }\end{array}$ & $\checkmark$ & \\
\hline 10. & $\begin{array}{l}\text { Entitas mengakui aset dan } \\
\text { liabilitas pajak penghasilan } \\
\text { dengan mengikuti peraturan } \\
\text { perpajakan yang berlaku. } \\
\text { (Paragraf 15.2) }\end{array}$ & $\begin{array}{l}\text { Usaha Sinar Terang tidak } \\
\text { mengakui pajak } \\
\text { penghasilan }\end{array}$ & & $\checkmark$ \\
\hline \multicolumn{3}{|c|}{ Total Jawaban } & 4 & 4 \\
\hline
\end{tabular}

Sumber: Data diolah, 2019

Analisis Deskriptif Komparatif Kesesuaian Berdasarkan SAK EMKM Dengan Yang Dilakukan Oleh Usaha Sinar Terang

Checklist Nilai kesesuaian pengukuran penetapan jumlah uang untuk mengakui aset, liabilitas, penghasilan dan beban di dalam laporan keuangan berdasarkan SAK EMKM dengan yang dilakukan oleh Usaha Sinar Terang sebagai berikut:

\section{Tabel 6 Hasil Perhitungan Kesesuaian Pengukuran}

PENGUKURAN

No. Berdasarkan SAK EMKM 


\begin{tabular}{|c|c|c|c|c|}
\hline & & Terang & Sesuai & $\begin{array}{l}\text { Tidak } \\
\text { Sesuai }\end{array}$ \\
\hline 1. & $\begin{array}{l}\text { Aset keuangan dan liabilitas } \\
\text { keuangan diukur sebesar biaya } \\
\text { perolehannya. (Paragraf 8.6) }\end{array}$ & $\begin{array}{l}\text { Usaha Sinar Terang } \\
\text { mengukur aset keuangan } \\
\text { dan liabilitas keuangan } \\
\text { sebesar biaya } \\
\text { perolehannya }\end{array}$ & $\checkmark$ & \\
\hline 2. & $\begin{array}{l}\text { Entitas dapat memilih } \\
\text { menggunakan metode masuk } \\
\text { pertama keluar pertama (MPKP) } \\
\text { atau rata-rata tertimbang dalam } \\
\text { menentukan biaya perolehan } \\
\text { persediaan. (Paragraf 9.6) }\end{array}$ & $\begin{array}{l}\text { Usaha Sinar Terang } \\
\text { tidak menggunakan } \\
\text { metode persediaan. } \\
\text { Karena dalam satu } \\
\text { periode produksi, } \\
\text { persediaan dinyatakan } \\
\text { habis terjual }\end{array}$ & $\checkmark$ & \\
\hline 3. & $\begin{array}{l}\text { Entitas mengukur seluruh aset } \\
\text { tetap, kecuali tanah, setelah } \\
\text { pengakuan awal pada biaya } \\
\text { perolehan dikurangi dengan } \\
\text { akumulasi penyusutan. Tanah } \\
\text { diukur pada biaya perolehan. } \\
\text { (Paragraf 11.9) }\end{array}$ & $\begin{array}{l}\text { Usaha Sinar Terang } \\
\text { belum mencatat dan } \\
\text { mengukur seluruh aset } \\
\text { tetap }\end{array}$ & & $\checkmark$ \\
\hline 4. & $\begin{array}{l}\text { Penyusutan aset tetap dapat } \\
\text { dilakukan dengan menggunakan } \\
\text { metode garis lurus atau metode } \\
\text { saldo menurun tanpa } \\
\text { memperhitungkan nilai residu } \\
\text { (nilai sisa). (Paragraf 11.14) }\end{array}$ & $\begin{array}{l}\text { Usaha Sinar Terang } \\
\text { belum mencatat dan } \\
\text { mengukur penyusutan } \\
\text { aset tetap }\end{array}$ & & $\checkmark$ \\
\hline 5. & $\begin{array}{l}\text { Entitas mengukur aset takberwujud } \\
\text { pada biaya perolehan dikurangi } \\
\text { dengan akumulasi amortisasi. } \\
\text { (Paragraf 12.8) }\end{array}$ & $\begin{array}{l}\text { Usaha Sinar Terang } \\
\text { tidak memiliki aset tak } \\
\text { berwujud }\end{array}$ & - & - \\
\hline 6. & $\begin{array}{l}\text { Ekuitas diukur sesuai dengan } \\
\text { peraturan perundangan yang } \\
\text { berlaku untuk badan usaha } \\
\text { tersebut. (Paragraf 13.9) }\end{array}$ & $\begin{array}{l}\text { Usaha Sinar Terang } \\
\text { tidak mengukur ekuitas }\end{array}$ & & $\checkmark$ \\
\hline \multicolumn{3}{|c|}{ Total Jawaban } & 2 & 3 \\
\hline
\end{tabular}

Sumber: Data diolah, 2019

Hasil perhitungan checklist kesesuaian pengukuran penetapan jumlah uang untuk mengakui aset, liabilitas, penghasilan dan beban di dalam laporan keuangan adalah :
Persentase $=$ $\frac{\sum \text { Jumlah jawaban "sesuai" }}{\sum \text { Total Pembanding }} \times 100 \%=$ $\frac{2}{5} \times 100 \%=40 \%$. 
Berdasarkan kriteria kesesuaian menurut Champion, maka capaian nilai kesesuaian sebesar $40 \%$ menunjukkan bahwa pengukuran pos-pos dalam

\section{Analisis Deskriptif Komparatif Penyajian Berdasarkan SAK EMKM Dengan Yang Dilakukan Oleh Usaha Sinar Terang}

Usaha Sinar Terang di Samarinda belum melakukan penyajian laporan keuangan menurut ketentuan SAK EMKM bahwa :

1. Entitas menyajikan aset keuangan dalam kelompok aset pada laporan posisi keuangan dan liabilitas keuangan dalam kelompok liabilitas pada laporan posisi keuangan. (Paragraf 8.15)

2. Persediaan disajikan dalam kelompok aset dalam laporan posisi keuangan. (Paragraf 9.8)

3. Aset tetap disajikan dalam kelompok aset dalam laporan posisi keuangan. (Paragraf 11.19)

4. Aset takberwujud disajikan dalam kelompok aset dalam laporan posisi keuangan. (Paragraf 12.15)

5. Modal saham, tambahan modal disetor dan saldo laba rugi disajikan

\section{Analisis Deskriptif Komparatif Pengungkapan Berdasarkan SAK EMKM Dengan Yang Dilakukan Oleh Usaha Sinar Terang}

laporan keuangan menurut Usaha Sinar Terang dikategorikan kurang sesuai dengan ketentuan dalam SAK EMKM Tahun 2018.

dalam kelompok ekuitas dalam laporan posisi keuangan. (Paragraf 13.11)

6. Pendapatan disajikan dalam kelompok pendapatan dalam laporan laba rugi. (Paragraf 14.16)

7. Entitas menyajikan pendapatan hibah sebagai bagian dalam laporan laba rugi, baik secara terpisah atau dalam pos "Pendapatan lain-lain". (Paragraf 14.17)

8. Beban disajikan dalam kelompok beban laporan laba rugi. (Paragraf 14.18).

sehingga dapat dikategorikan dalam tingkat kesesuaian penyajian penempatan suatu akun secara terstruktur pada laporan keuangan sebesar $0 \%$ yang menunjukkan bahwa penyajian penempatan suatu akun secara terstruktur pada laporan keuangan menurut Usaha Sinar Terang dikategorikan tidak sesuai dengan ketentuan penyajian berdasarkan SAK EMKM Tahun 2018.

Usaha Sinar Terang di Samarinda belum melakukan pengungkapan 
laporan keuangan menurut ketentuan SAK EMKM bahwa sehingga dapat dikategorikan dalam tingkat kesesuaian pengungkapan penjelasan secara naratif atau rincian angka-angka yang tertera dalam laporan posisi keuangan dan laporan laba rugi sebesar $0 \%$. Hal ini menunjukkan bahwa pengungkapan penjelasan secara naratif atau rincian angka-angka yang tertera dalam laporan posisi keuangan dan laporan laba rugi menurut Usaha Sinar Terang dikategorikan tidak sesuai dengan ketentuan SAK EMKM Tahun 2018

\section{Pembahasan}

Hasil analisis menunjukkan bahwa ketentuan SAK EMKM tentang pengakuan dan pengukuran sudah dilakukan oleh Usaha Sinar Terang Di Samarinda, namun kurang sesuai dengan ketentuan pengakuan berdasarkan SAK EMKM. Sedangkan penyajian dan pengungkapan belum dilakukan. Hal ini terlihat dari Pengakuan pos-pos dalam laporan keuangan pada Usaha Sinar Terang berupa pengakuan aset tetap, pengakuan beban penyusutan, pengakuan ekuitas dan pengakuan pajak penghasilan yang dapat dijelaskan bahwa: Usaha Sinar Terang tidak mencatat adanya aset tetap tetapi entitas tersebut mengakui bahwa adanya aset tetap yang berupa bangunan, kendaraan dan peralatan yang diakui sebesar biaya perolehannya. Demikian pula beban penyusutan aset tetap, Usaha Sinar Terang tidak mengakui sebagaimana yang diisyaratkan SAK EMKM Tahun 2018. Usaha Sinar Terang tidak mengakui secara keseluruhan ekuitasnya karena belum membuat laporan keuangan, Usaha Sinar Terang hanya mengakui aset dan liabilitas secara terpisah.Usaha Sinar Terang bukan merupakan wajib pajak badan yang masuk dalam kategori wajib pajak penghasilan, pengenaan pajak penghasilan dikenakan kepada pemilik Usaha Sinar Terang sebagai pajak penghasilan pribadi yang diatur sesuai Peraturan Pemerintah Republik Indonesia nomor 23 Tahun 2018.Temuan ini dapat membuktikan hipotesis bahwa pengakuan pos-pos dalam laporan keuangan pada Usaha Sinar Terang dinyatakan cukup sesuai berdasarkan SAK EMKM Tahun 2018. Pengukuran dalam laporan keuangan pada Usaha Sinar Terang yang belum sesuai dengan SAK EMKM Tahun 2018 adalah bagian pengukuran aset tetap, pengukuran penyusutan aset tetap dan pengukuran ekuitas.Usaha Sinar Terang hanya membuat laporan 
pembukuan sederhana yang hanya berisi transaksi-transakasi yang terjadi

dalam satu bulan.

Usaha Sinar terang dapat mengukur aset tetap kecuali tanah, setelah pengakuan awal pada biaya perolehan dikurangi dengan akumulasi penyusutan sebagaimana yang diisyaratkan SAK EMKM Tahun 2018 dan untuk pengukuran ekuitas. Adapun evaluasi pengukuran aset tetap dan penyusutan aset tetap pada Usaha Sinar Terang per 31 Januari 2019 sebagai berikut:

Tabel 7 Pengukuran Penyusutan Aset Tetap

\begin{tabular}{rlrrrr}
\hline No & \multicolumn{1}{c}{ Aset Tetap } & $\begin{array}{c}\text { Jumlah } \\
\text { Unit }\end{array}$ & Nilai Perolehan (Rp) & $\begin{array}{c}\text { Masa } \\
\text { Manfaat } \\
\text { (Bulan) }\end{array}$ & $\begin{array}{c}\text { Penyusutan Per } \\
\text { Bulan (Rp) }\end{array}$ \\
\hline 1. & Bangunan & 1 & 300.000 .000 & 240 & 1.250 .000 \\
\hline 2. & Kendaraan & 1 & 210.000 .000 & 96 & 2.187 .500 \\
\hline 3. & Peralatan : & & & & \\
\hline Timbangan Duduk & 2 & 330.000 & 96 & 3.438 \\
\hline Meja Adonan & 1 & 500.000 & 48 & 10.417 \\
\hline Mesin Giling & 1 & 2.800 .000 & 96 & 29.167 \\
\hline Mesin Pres & 2 & 1.500 .000 & 48 & 31.250 \\
\hline Blender & 1 & 750.000 & 48 & 15.625 \\
\hline Wajan Besar & 1 & 600.000 & 96 & 6.250 \\
\hline Kompor Seribu Mata & 1 & 1.100 .000 & 96 & 11.458 \\
\hline Tungku & 1 & 100.000 & 96 & 1.042 \\
\hline Serokan Besar & 1 & 50.000 & 48 & 1.042 \\
\hline Pisau & 3 & 75.000 & 96 & 781 \\
\hline Box Penampung ikan & 1 & 600.000 & 48 & 12.500 \\
\hline Etalase & 1 & 2.000 .000 & 96 & 20.833 \\
\hline \multicolumn{1}{c}{ Total Peralatan } & & 10.405 .000 & & 143.803 \\
\hline
\end{tabular}

Sumber : Data diolah, 2019

Pengukuran nilai aset tetap yang dimiliki Usaha Sinar Terang, yaitu:

Tabel 8 Pengukuran Nilai Aset Tetap

\begin{tabular}{|c|c|c|c|c|c|c|}
\hline No & Aset Tetap & $\begin{array}{c}\text { Nilai } \\
\text { Perolehan } \\
\text { (Rp) }\end{array}$ & $\begin{array}{l}\text { Pemakaian } \\
\text { (Bulan) }\end{array}$ & $\begin{array}{c}\text { Penyusutan } \\
\text { Per Bulan } \\
\text { (Rp) } \\
\end{array}$ & $\begin{array}{c}\text { Akumulasi } \\
\text { Penyusutan } \\
\text { (Rp) }\end{array}$ & $\begin{array}{c}\begin{array}{c}\text { Nilai Aset } \\
\text { Tetap }\end{array} \\
\text { (Rp) } \\
\end{array}$ \\
\hline 1. & Bangunan & 300.000 .000 & 24 & 1.250 .000 & 30.000 .000 & 270.000 .000 \\
\hline 2. & Kendaraan & 210.000 .000 & 60 & 2.187 .500 & 131.250 .000 & 78.750 .000 \\
\hline \multirow[t]{9}{*}{3.} & Peralatan & & & & & \\
\hline & Timbangan Duduk & 330.000 & 60 & 3.438 & 206.280 & 123.720 \\
\hline & Meja Adonan & 500.000 & 24 & 10.417 & 250.008 & 249.992 \\
\hline & Mesin Giling & 2.800 .000 & 60 & 29.167 & 1.750 .020 & 1.049 .980 \\
\hline & Mesin Pres & 1.500 .000 & 36 & 31.250 & 1.125 .000 & 375.000 \\
\hline & Blender & 750.000 & 24 & 15.625 & 375.000 & 375.000 \\
\hline & Wajan Besar & 600.000 & 60 & 6.250 & 375.000 & 225.000 \\
\hline & $\begin{array}{l}\text { Kompor Seribu } \\
\text { Mata }\end{array}$ & 1.100 .000 & 60 & 11.458 & 687.480 & 412.520 \\
\hline & Tungku & 100.000 & 60 & 1.042 & 62.520 & 37.480 \\
\hline
\end{tabular}




\begin{tabular}{lrrrrr}
\hline Serokan Besar & 50.000 & 24 & 1.042 & 25.008 & 24.992 \\
\hline Pisau & 75.000 & 60 & 781 & 46.860 & 28.140 \\
\hline $\begin{array}{l}\text { Box Penampung } \\
\text { ikan }\end{array}$ & 600.000 & 24 & 12.500 & 300.000 & 300.000 \\
\hline Etalase & 2.000 .000 & 60 & 20.833 & 1.125 .000 & 675.000 \\
\hline Total Peralatan & 10.405 .000 & & 143.803 & 6.453 .176 & 3.951 .824 \\
\hline
\end{tabular}

Sumber : Data Diolah,2018

Pengukuran penyusutan aset

tetap menggunakan metode garis lurus tanpa memperhitungkan nilai residu (nilai sisa). Penentuan kelompok harta berwujud dan masa manfaat berdasarkan pada Undang-Undang Nomor 36 Tahun 2008 dan Peraturan Menteri Keuangan Republik Indonesia nomor 96/PMK.03/2009. Ulasan tersebut telah membuktikan bahwa pengukuran laporan keuangan pada Usaha Sinar Terang kurang sesuai dengan Standar Akuntansi Keuangan Entitas Mikro Kecil dan Menengah (SAK EMKM) Tahun 2018.

Penyajian laporan keuangan belum dilakukan Usaha Sinar Terang ketentuan yang termaktup dalam SAK EMKM Tahun 2018. Hal tersebut dikarenakan pemilik usaha yang sekaligus sebagai bagian keuangan belum mengetahui bagaimana menyusun laporan keuangan sesuai standarnya, sehingga Usaha Sinar Terang hanya melakukan laporan pembukuan sederhana berdasarkan pemahaman pemilik usaha. Adapun evaluasi penyajian laporan keuangan Usaha Sinar Terang berdasarkan SAK EMKM Tahun 2018 untuk periode 31 Januari 2019 adalah sebagi berikut :

a. Laporan Laba Rugi Usaha Sinar Terang

Tabel 9 Laporan Laba Rugi Usaha Sinar Terang

USAHA SINAR TERANG

\section{LAPORAN LABA RUGI}

31-Jan-19

(Rp)

\begin{tabular}{lr}
\hline PENDAPATAN & \\
\hline Pendapatan Usaha & 46.061 .500 \\
\hline JUMLAH PENDAPATAN & \\
\hline BEBAN & $\mathbf{4 6 . 0 6 1 . 5 0 0}$ \\
\hline Beban Air & 335.821 \\
\hline Beban Listrik & 379.585 \\
\hline Beban Gaji dan Upah & 8.800 .000 \\
\hline Beban BBM & 700.000 \\
\hline Beban Perawatan & 450.000 \\
\hline Beban Konsumsi & 900.000 \\
\hline Beban Bunga & 200.000
\end{tabular}


Beban Penyusutan Bangunan

1.250 .000

Beban Penyusutan Kendaraan

2.187 .500

Beban Penyusutan Peralatan

143.803

JUMLAH BEBAN

15.346 .709

LABA SEBELUM PAJAK PENGHASILAN

15.346.709

Beban Pajak Penghasilan

LABA SETELAH PAJAK PENGHASILAN

30.714.791

b. Laporan posisi keuangan Usaha Sinar Terang :

Tabel 10 Laporan Laba Rugi Usaha Sinar Terang

USAHA SINAR TERANG

LAPORAN POSISI KEUANGAN

31-Jan-19

\begin{tabular}{ll}
\hline \multicolumn{2}{c}{ (Rp) } \\
\hline ASET & \\
\hline Kas & 40.000 .000 \\
\hline Kas Bank BNI & 51.746 .250 \\
\hline
\end{tabular}

Jumlah Kas

91.746.250

Piutang Usaha

17.650 .000

Persediaan

Beban Dibayar Dimuka

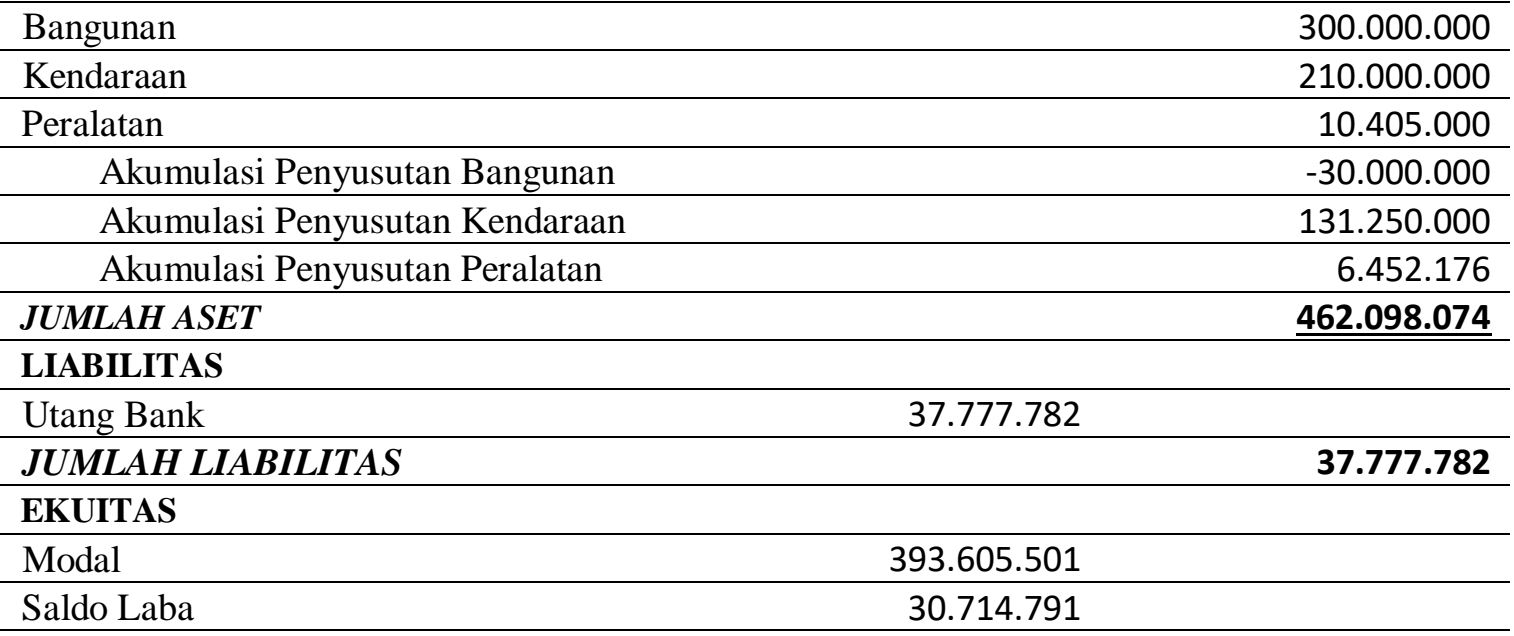

JUMLAH EKUITAS

424.320 .292

JUMLAH LIABILITAS DAN EKUITAS

462.098.074

Sumber : Data Diolah,2019

Temuan ini menerima hipotesis

dalam penelitian bahwa penyajian laporan keuangan pada Usaha Sinar

Terang tidak sesuai dengan ketentuan dalam SAK EMKM) Tahun 2018.

Pegungkapan laporan keuangan

Terang, maka dapat dikatakan tidak sesuai dengan SAK EMKM, dengan demikian hipotesis penelitian ini diterima. Bila dibuat maka pengungkapan laporan keuangan Usaha Sinar Terang berdasarkan SAK EMKM belum dilakukan oleh Usaha Sinar 
Tahun 2018 periode 31 Januari 2019

adalah sebagai berikut :

Tabel 11 Catatan Atas Laporan Keuangan

USAHA SINAR TERANG

CATATAN ATAS LAPORAN KEUANGAN

31 JANUARI 2019

(Rp)

1. UMUM

Usaha Sinar Terang didirikan di Samarinda pada tanggal 12 Juni 2009 oleh Ibu Sarinah yang kemudian dilanjutkan oleh anaknya yaitu Bapak Samsul Ma'arif. Usaha Sinar Terang bergerak dalam bidang usaha manufaktur.Usaha Sinar Terang Tergolong dalam usaha mikro,kecil dan menengah yang diatur dalamUU No 20 Tahun 2008. Usaha Sinar Terang berdomisili di Jl. M.Said,Gang Poliwali, RT 30 N0.04 Kel Lok Bahu, Kecamatan Sungai Kunjang, Kota Samarinda,Propinsi Kalimantan Timur

\section{IKTISAR KEBIJAKAN AKUNTANSI PENTING}

\section{a. Persyaratan Kepatuhan}

Laporan Keuangan Usaha Sinar Terang disusun menggunakan Standar Akuntansi Entitas Mikro, Kecil, dan Menengah Tahun 2018

b. Dasar penyusunan

Dasar penyusunan Laporan Keuangan Usaha Sinar Terang adalah biaya historis dan menggunakan asumsi dasar akrual, Mata uang yang digunakan untuk penyusunan laporan keuangan adalah Rupiah

c. Piutang Usaha

Piutang usaha disajikan sejumlah tagihan

\section{d. Persediaan}

Biaya persediaan bahan baku meliputi biaya pembelian dan biaya angkut pembelian. Biaya konversi meliputi biaya tenaga kerja langsung dan overhead. Overhead tetap dialokasikan ke biaya konversi berdasarkan kapasitas produksi normal

e. Aset Tetap

Aset tetap dicatat sebesar biaya perolehannya jika aset tersebut dimiliki secara hukum oleh Usaha Sinar Terang. Aset tetap disusutkan menggunakan metode garis lurus tanpa nilai residu

\section{f. Pengakuan Pendapatan dan Beban}

Pendapatan penjualan diakui ketika tagihan diterbitkan kepada pelanggan. Beban diakui saat terjadi

\section{g. Pajak Penghasilan}

Pajak penghasilan mengikuti ketentuan perpajakan yang berlaku di Indonesia

\section{KAS}
Kas
Januari 2019
Rp 91.746.250

\section{PIUTANG USAHA}

Era Mart

\section{Januari 2019}

\section{UTANG BANK}

Rp 17.650.000

Pada tanggal 1 Juni 2017, Usaha Sinar Terang memperoleh pinjaman Kredit Usaha Rakyat (KUR) dari PT Bank BNI dengan kredit Rp. 80.000.000, suku bunga efektif 9\% per tahun dengan jatuh tempo setiap tanggal 30 akhir bulan selama 3 tahun. 
Pinjaman dijamin dengan sebidang tanah milik pemilik Usaha Sinar Terang.

6. SALDO LABA

Saldo laba merupakan akumulasi selisih penghasilan dan beban Usaha Sinar Terang. Saldo laba per 31 Januari 2019 sebesar Rp. 30.714 .791

7. PENDAPATAN DAN PENJUALAN

Penjualan

Retur Penjualan

Jumlah

Januari 2019

Rp 46.690.000

Rp $\quad 628.500$

$\mathrm{Rp} 46.690 .000$

Sumber : Data diolah, 2019

\section{KESIMPULAN DAN SARAN}

\section{Kesimpulan}

Berdasarkan hasil analisis dan pembahasan disimpulkan bahwa :

1. Pengakuan pos-pos dalam laporan keuangan Pada Usaha Sinar Terang kurang sesuai dengan ketentuan dalam SAK EMKM. Pengakuan pos akun yang belum sesuai dengan SAK EMKM adalah bagian pengakuan aset tetap, pengakuan beban penyusutan, pengakuan ekuitas dan pengakuan pajak penghasilan.

2. Pengukuran dalam laporan keuangan pada Usaha Sinar Terang kurang sesuai SAK EMKM. Pengukuran aset tetap dan penyusutannya belum sesuai dengan SAK EMKM Tahun 2018

3. Usaha Sinar Terang belum menyajikan laporan keuangan berdasarkan SAK EMKM Tahun 2018
4. Usaha Sinar Terang belum melakukan pegungkapan laporan keuangan berdasarkan SAK EMKM Tahun 2018

\section{Saran}

Berdasarkan Kesimpulan maka disarankan agar Usaha Sinar Terang sebaiknya menerapkan perlakuan akuntansi pengakuan, pengukuran, penyajian dan pengungkapan sesuai dengan SAK EMKM sehingga dapat memberikan kemudahan dalam menyusun laporan keuangan yang terdiri dari laporan laba rugi, laporan posisi keuangan dan catatan atas laporan keuangan yang bermanfaat untuk meningkatkan kualitas usaha dan sebagai solusi permasalahan internal.

\section{DAFTAR PUSTAKA}

Anonim, Ikatan Akuntansi Indonesia. 2018. Standar Akuntansi Keuangan Entitas Mikro Kecil dan Menengah (EMKM). Iaiglobal.or.id. 
Undang-Undang Republik Indonesia Nomor 20 Tahun 2008 Tentang Usaha Mikro, Kecil dan Menengah. bi.go.id.https:/www.bi.go.id/id/ tentangbi/uubi/Documents/UU 20Tahun2008UMKM.pdf.

Undang-Undang Republik Indonesia Nomor 36 Tahun 2008 Tentang Pajak Penghasilan.jdih.esdm.go.id.htt ps://jdih.esdm.go.id/peraturan/ UU\%20No.\%2036\%20Thn\%2 02008 .
Champion, Dean J. 1990. Basic Statistic For Socian Reaserch. Adition, New York : Mac Media

Kasmir. 2018. Analisis Laporan Keuangan.Depok

Rajagrafindo Persada

Kieso, Donald E. et. al.2016. Intermediate Accounting. United Satates Of America : Writed Satates of America

Munawir, S. 2018. Analisa Laporan Keuangan. Yogyakarta: Liberty 